\title{
Density of GABAB Receptors Is Reduced in Granule Cells of the Hippocampus in a Mouse Model of Alzheimer's Disease
}

\author{
Alejandro Martín-Belmonte ${ }^{1}{ }^{\mathbb{D}}$, Carolina Aguado ${ }^{1}$, Rocío Alfaro-Ruíz ${ }^{1}$, \\ Ana Esther Moreno-Martínez ${ }^{1}$, Luis de la Ossa ${ }^{2}$, José Martínez-Hernández ${ }^{1,+}{ }^{+}$, Alain Buisson ${ }^{3}{ }^{(\mathbb{B}}$, \\ Ryuichi Shigemoto ${ }^{4}{ }^{-}$, Yugo Fukazawa ${ }^{5,6,7}$ and Rafael Luján ${ }^{1, *}$
}

1 Synaptic Structure Laboratory, Instituto de Investigación en Discapacidades Neurológicas (IDINE), Dept. Ciencias Médicas, Facultad de Medicina, Universidad Castilla-La Mancha, Campus Biosanitario, C/Almansa 14, 02008 Albacete, Spain; Alejandro.Martin@uclm.es (A.M.-B.); Carolina.Aguado@uclm.es (C.A.); Rocio.Alfaro@uclm.es (R.A.-R.); AnaEsther.Moreno@uclm.es (A.E.M.-M.); drmartinezhernandez@gmail.com (J.M.-H.)

2 Departamento de Sistemas Informáticos, Escuela Superior de Ingeniería Informática, Universidad de Castilla-La Mancha, 02071 Albacete, Spain; luis.delaossa@uclm.es

3 Grenoble Institut des Neurosciences, Université Grenoble Alpes, BP 170 Grenoble, France; alain.buisson@univ-grenoble-alpes.fr

4 Institute of Science and Technology (IST Austria), Am Campus 1, A-3400 Klosterneuburg, Austria; ryuichi.shigemoto@ist.ac.at

5 Division of Brain Structure and Function, Faculty of Medical Science, University of Fukui, Fukui 910-1193, Japan; yugo@u-fukui.ac.jp

6 Life Science Innovation Center, University of Fukui, Fukui 910-1193, Japan

7 Research Center for Child Mental Development, Faculty of Medical Science, University of Fukui, Fukui 910-1193, Japan

* Correspondence: Rafael.Lujan@uclm.es; Tel.: +34-967-599200 (ext. 2196)

+ Present address: University of the Basque Country (UPV/EHU), 48940 Leioa, Spain. Ikerbasque, Basque Foundation for Science, 48013 Bilbao, Spain.

Received: 30 January 2020; Accepted: 31 March 2020; Published: 2 April 2020

check for updates

\begin{abstract}
Metabotropic $\gamma$-aminobutyric acid $\left(\mathrm{GABA}_{\mathrm{B}}\right)$ receptors contribute to the control of network activity and information processing in hippocampal circuits by regulating neuronal excitability and synaptic transmission. The dysfunction in the dentate gyrus (DG) has been implicated in Alzheimer's disease $(\mathrm{AD})$. Given the involvement of $\mathrm{GABA}_{\mathrm{B}}$ receptors in $\mathrm{AD}$, to determine their subcellular localisation and possible alteration in granule cells of the $\mathrm{DG}$ in a mouse model of $\mathrm{AD}$ at 12 months of age, we used high-resolution immunoelectron microscopic analysis. Immunohistochemistry at the light microscopic level showed that the regional and cellular expression pattern of $\mathrm{GABA}_{\mathrm{B} 1}$ was similar in an AD model mouse expressing mutated human amyloid precursor protein and presenilin1 (APP/PS1) and in age-matched wild type mice. High-resolution immunoelectron microscopy revealed a distance-dependent gradient of immunolabelling for $\mathrm{GABA}_{B}$ receptors, increasing from proximal to distal dendrites in both wild type and APP/PS1 mice. However, the overall density of GABA $B$ receptors at the neuronal surface of these postsynaptic compartments of granule cells was significantly reduced in APP/PS1 mice. Parallel to this reduction in surface receptors, we found a significant increase in $\mathrm{GABA}_{\mathrm{B} 1}$ at cytoplasmic sites. $\mathrm{GABA}_{\mathrm{B}}$ receptors were also detected at presynaptic sites in the molecular layer of the DG. We also found a decrease in plasma membrane $G_{A B A}$ receptors in axon terminals contacting dendritic spines of granule cells, which was more pronounced in the outer than in the inner molecular layer. Altogether, our data showing post- and presynaptic reduction in surface $G_{A B A}$ receptors in the $D G$ suggest the alteration of the $G_{A B A}$-mediated modulation of excitability and synaptic transmission in granule cells, which may contribute to the cognitive dysfunctions in the APP/PS1 model of AD.
\end{abstract}


Keywords: Alzheimer's disease; hippocampus; $\mathrm{GABA}_{\mathrm{B}}$ receptors; ion channels; immunohistochemistry; electron microscopy; freeze-fracture; mouse model; dentate gyrus

\section{Introduction}

The dentate gyrus (DG) is an integral part of the hippocampal formation and play key roles in the formation of episodic memory, spatial memory and exploration of new environments [1]. To fulfil these functions, the DG is highly organised and numerous synaptic connections take place between granule cells and basket cells, the principal cells and the primary inhibitory interneuron of the DG, respectively [1,2]. The major input of the DG arises from entorhinal cortex layer II neurons through the perforant path, and the functional integrity of this connection is necessary to fulfil its function in memory formation and spatial navigation [3]. Therefore, dysfunction in this entorhinal cortex-dentate gyrus pathway has been implicated in pathological conditions like Alzheimer's disease (AD), the most prevalent neurodegenerative disease in the elderly population.

During progression of $\mathrm{AD}$, neurodegeneration begins in the entorhinal cortex and then propagates to the adjacent regions, starting in the DG [4]. The three major neuropathology hallmarks of AD are extracellular fibrillary amyloid beta peptide $(\mathrm{A} \beta)$ in amyloid plaques, intraneuronal neurofibrillary tangles consisting of aggregated hyperphosphorylated tau and synapse loss [5]. Only loss of synapses has been correlated with cognitive decline and proposed to underlie learning and memory deficits in AD [6]. The vast majority of synapses in the DG of the hippocampus are glutamatergic excitatory synapses, and the main targets of these synapses are the dendritic spines of granule cells. Given the critical role of dendritic spines in memory, learning, and cognition, the loss of dendritic spines has been reported in the DG in AD [7-9] and in the APP/PS1 mouse model [10]. In addition, an impairment of adult neurogenesis has been reported in the DG in AD patients [11].

Granule cells in the DG are inhibited by $\gamma$-aminobutyric acid (GABA) synaptically released by interneurons. The response to GABA is mediated by activation of both ionotropic $\left(\mathrm{GABA}_{\mathrm{A}}\right)$ and metabotropic $\left(G A B A_{B}\right)$ receptors $[12,13]$. The activation of $G A B A_{B}$ receptors is coupled to intracellular signal transduction mechanisms via G-proteins, mediating slow and prolonged synaptic inhibition through the activation of postsynaptic inwardly rectifying $\mathrm{K}^{+}$channels and inhibition of presynaptic voltage-gated $\mathrm{Ca}^{2+}$ channels $[13,14]$. Acting on these effector ion channels, $\mathrm{GABA}_{\mathrm{B}}$ receptors have modulatory actions on neuronal excitability and neurotransmitter release, and are involved in a number of physiological and pathophysiological processes [13]. Growing evidence supports the involvement of $\mathrm{GABA}_{\mathrm{B}}$ receptors in $\mathrm{AD}$ [15-19].

Two different $C D N A$ s encoding $G_{A B A}$ receptor subunits have been cloned to date: $G_{A B} A_{B 1}$ and $G_{A B A}[20,21]$. Both receptor subunits are required to form functional receptors, with the GABA $B 1$ subunit being necessary for agonist activation and the $\mathrm{GABA}_{\mathrm{B} 2}$ subunit for surface trafficking and G-protein coupling [22-25]. Previous studies using different technical approaches showed that all sub-regions of the hippocampus, including the DG, express a high density of $G A B A_{B}$ receptors [20,26-28]. Immunoelectron microscopic studies demonstrated the main post- and pre-synaptic association of $\mathrm{GABA}_{B}$ receptors, mainly with excitatory synapses in dendritic spines of CA1 pyramidal cells and granule cells of the DG [28-31]. In addition, we have recently reported a dramatic reduction in $\mathrm{GABA}_{B}$ receptors along the postsynaptic plasma membrane of CA1 pyramidal cells, as well as at presynaptic sites in the excitatory synapses between Schaffer collateral-CA1 pyramidal cell spines in APP/PS1 mice [17]. Whether this alteration takes place in other principal cells of the hippocampus, such as granule cells, in the AD model mice is not yet known.

Given the loss of dendritic spines and excitatory synapses in the DG in APP/PS1 mice [10], it is expected that $G_{A B A}$ receptors are also affected. Therefore, to identify possible alterations in the cellular and subcellular localisation of $\mathrm{GABA}_{B}$ receptors in this mouse model, we used high-resolution immunohistochemical techniques in combination with quantitative approaches at 12 months of age, a 
time when these animals show a large density of senile plaques and cognitive impairments $[32,33]$ and when $\mathrm{GABA}_{\mathrm{B}}$ receptors are altered along the surface of CA1 pyramidal cells [17]. Our data demonstrate for the first time a significant reduction in the surface expression of $\mathrm{GABA}_{\mathrm{B}}$ receptors in the granule cells of the DG in APP/PS1 mice.

\section{Results}

\subsection{Regional and Cellular Distribution of $G A B A_{B 1}$ in the DG of Control and APP/PS1 Mice}

We first investigated the regional and cellular distribution of $\mathrm{GABA}_{\mathrm{B} 1}$ in the DG in wild type and APP/PS1 mice at 12 months of age, using light microscopy immunohistochemical techniques (Figure 1). In both genotypes, immunoreactivity for $\mathrm{GABA}_{\mathrm{B} 1}$ was the highest in the molecular layer, weak in the hilus and weakest in the granule cell layer of the DG (Figure 1A-H). At the cellular level, GABA immunoreactivity was weekly detected in the somata of granule cells but strongly expressed on their dendrites in the molecular layer at their default dendritic localisation (Figure 1C,D,F,G). GABA $A_{B 1}$ immunoreactivity was also observed on basket cells, a type of GABAergic interneuron located along the interface between the granule cell layer and the polymorphic layer of the hilus (Figure 1D,G). In the hilus, hilar neurons were intensely labelled for $\mathrm{GABA}_{\mathrm{B} 1}$, showing somatic expression of the subunit (Figure 1E,H). The accumulation of A $\beta$ in APP/PS1 mice was high throughout the molecular layer of the DG, and particularly high in the outer two thirds of this layer compared to age-matched wild type mice (Figure 1I,J). In spite of the large accumulation of A $\beta$ in the DG of APP/PS1 mice, the regional and cellular distributions for $\mathrm{GABA}_{\mathrm{B} 1}$ were very similar between wild and APP/PS1 mice (Figure 1A-H).

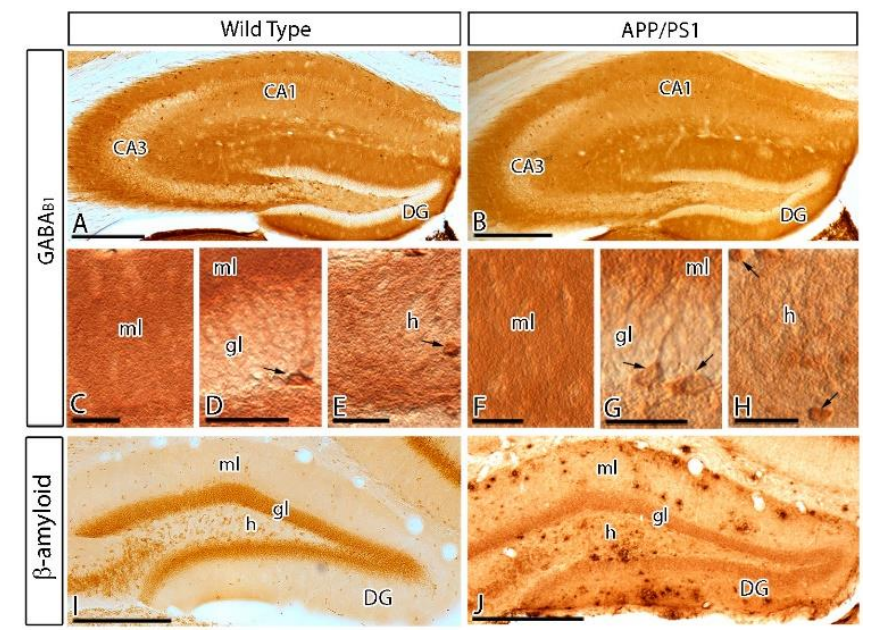

Figure 1. Regional and cellular distribution of the metabotropic $\gamma$-aminobutyric acid $\mathrm{GABA}_{\mathrm{B} 1}$ subunit $\left.\left(G_{A B A}\right)_{1}\right)$ in wild type and APP/PS1 mice. (A-H) Immunoreactivity for GABA $_{B 1}$ in the dentate gyrus (DG) of wild type and APP/PS1 mice at 12 months of age using an immunohistochemical method at the light microscopic level. Immunoreactivity for $\mathrm{GABA}_{\mathrm{B} 1}$ was very similar both in the wild type and the APP/PS1 mice. Labelling for $\mathrm{GABA}_{\mathrm{B} 1}$ showed the highest intensity in molecular layer (ml) of the DG and weaker in the granule cell layer (gl). Immunoreactivity for $\mathrm{GABA}_{\mathrm{B} 1}$ was also detected in pyramidal basket cells (arrows) located in the granule cell layer and hilar neurons (arrows located in the hilus (h)), with similar distribution pattern and labelling intensity in wild type and APP/PS1 mice. $(\mathbf{I}, \mathbf{J})$ Immunoreactivity for $\beta$-amyloid in wild type and APP/PS1 mice, showing high accumulation of $A \beta$ throughout all layers of the DG, and particularly high expression in the outer molecular layer. Abbreviations: CA1 region of the hippocampus (CA1); CA3 region of the hippocampus (CA3); dentate gyrus (DG); molecular layer (ml); granule cell layer (gc); hilus (h). Scale bars: A,B,I,J $200 \mu \mathrm{m} ; \mathbf{C}-\mathbf{H}$, $30 \mu \mathrm{m}$. 


\subsection{Reduction in $G A B A_{B 1}$ in the Postsynaptic Cell Surface of Granule Cells in APP/PS1 Mice}

We recently reported that $\mathrm{GABA}_{B}$ receptors are altered in CA1 pyramidal cells in the APP/PS1 mouse model of $\mathrm{AD}$ at 12 months of age [17]. To investigate whether other principal cells of the hippocampus are also affected, we used the highly sensitive sodium dodecyl sulfate (SDS)-digested freeze-fracture replica labeling (SDS-FRL)method [34]. To unravel the organisation of $G_{A B A}$ along the surface of granule cells, the subcellular localisation of $\mathrm{GABA}_{\mathrm{B} 1}$ was investigated in sections of the DG obtained from wild type and APP/PS1 mice at 12 months of age. Using our ultrastructural approach, we detected immunoparticles for $\mathrm{GABA}_{\mathrm{B} 1}$ along the plasma membrane of the entire somato-dendritic compartment of granule cells, both in wild type (Figure 2) and APP/PS1 mice (Figure 3), but with notable quantitative differences (Figure 4) as described below.

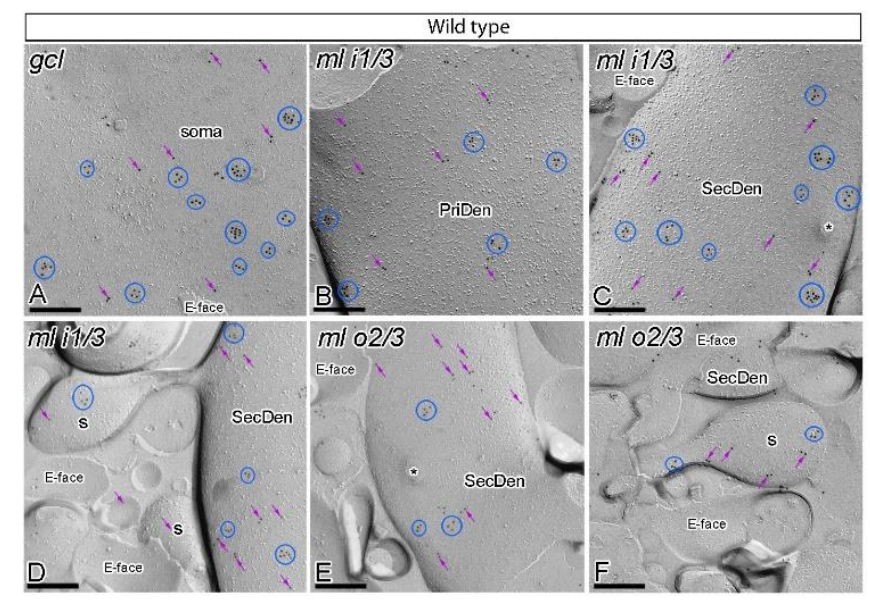

Figure 2. Subcellular localisation of $\mathrm{GABA}_{\mathrm{B} 1}$ in somato-dendritic domains of granule cells in wild type mice. (A-F) Electron micrographs obtained from different parts of the DG showing immunoparticles for $\mathrm{GABA}_{\mathrm{B} 1}$ along the surface of granule cells, as detected using the SDS-FRL technique in wild type mice at 12 months of age. Immunoparticles for $\mathrm{GABA}_{\mathrm{B} 1}$ were detected forming clusters (blue ellipses/circles) or scattered (purple arrows) associated with the P-face in the soma, primary dendrites (PriDen), secondary dendrites (SecDen) and dendritic spines (s) of both the outer two thirds (ml o2/3) and inner one third $(\mathrm{ml} \mathrm{i1/3)}$ of the molecular layer. Fractured spine necks are indicated with asterisks $\left.{ }^{*}\right)$. The E-face is free of any immunolabelling. Scale bars: A-F, $0.2 \mu \mathrm{m}$.

In wild type mice, immunoparticles for $\mathrm{GABA}_{\mathrm{B} 1}$ were abundantly detected in dendritic spines and dendritic shafts throughout the molecular layer, and also in the somata of granule cells in the granule cell layer (Figure 2A-F). In the six neuronal compartments of granule cells analysed, GABA $A_{B}$ immunoparticles were found forming clusters (an aggregation of more than three gold particles) or scattered (one or two isolated gold particles) (Figure 2A-F). Most immunoparticles were observed in clusters and less frequently scattered in the somata (Figure 2A) and dendritic compartments in the inner one third (Figure 2B-D) and outer two thirds (Figure 2E,F) of the molecular layer. Virtually no labelling was observed on the E-face or on cross-fractures (Figure 2A-F).

In APP/PS1 mice, GABA $\mathrm{B}_{1}$ immunoparticles were observed in dendritic spines, dendritic shafts and somata of granule cells (Figure $3 \mathrm{~A}-\mathrm{F}$ ). However, the intensity of $\mathrm{GABA}_{\mathrm{B} 1}$ changed significantly in the six neuronal compartments of granule cells analysed. Fewer immunoparticles per cluster and fewer clustered and scattered immunoparticles were detected along the neuronal surface of DG granule cells (Figure 3A-F). Similarly, as with the wild type, no labelling was observed on the E-face or on cross-fractures in APP/PS1 mice (Figure 3A-F). 


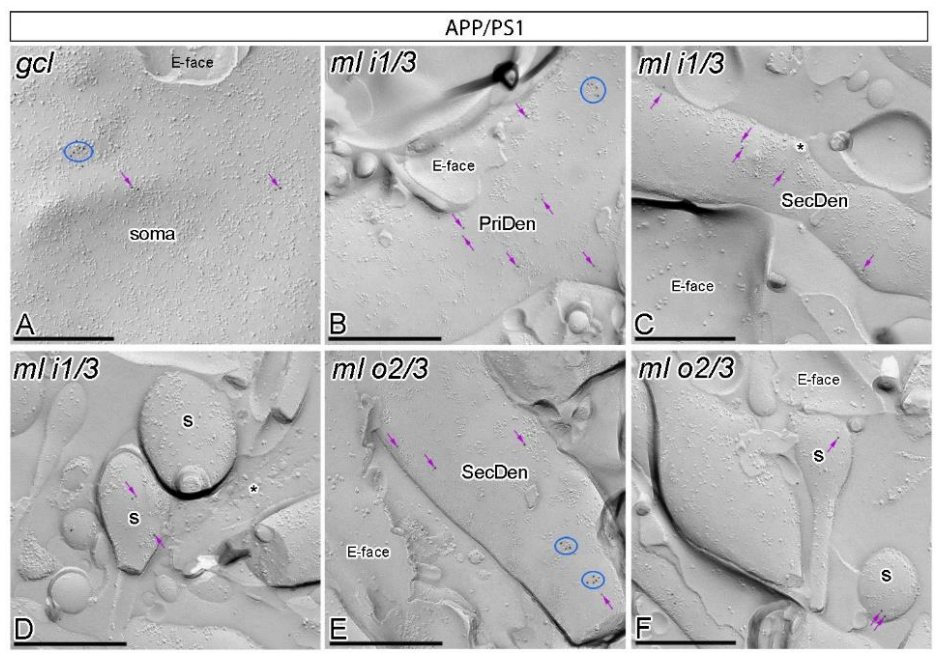

Figure 3. Subcellular localisation of $\mathrm{GABA}_{\mathrm{B} 1}$ in somato-dendritic domains of granule cells in APP/PS1 mice. (A-F) Electron micrographs obtained from different parts of the DG showing immunoparticles for $\mathrm{GABA}_{\mathrm{B} 1}$ along the surface of granule cells, as detected using the SDS-FRL technique in APP/PS1 mice at 12 months of age. Immunoparticles for $\mathrm{GABA}_{\mathrm{B} 1}$ were detected at lower frequency forming clusters (blue ellipses/circles) or scattered (purple arrows) associated with the P-face in the soma, primary dendrites (PriDen), secondary dendrites (SecDen) and dendritic spines (s) of both the outer two thirds $(\mathrm{ml} \mathrm{o} / 3)$ and inner one third $(\mathrm{ml} \mathrm{i1/3)}$ of the molecular layer. Fractured spine necks are indicated with asterisks $\left({ }^{*}\right)$. The E-face is free of any immunolabelling. Scale bars: A-F, $0.2 \mu \mathrm{m}$.

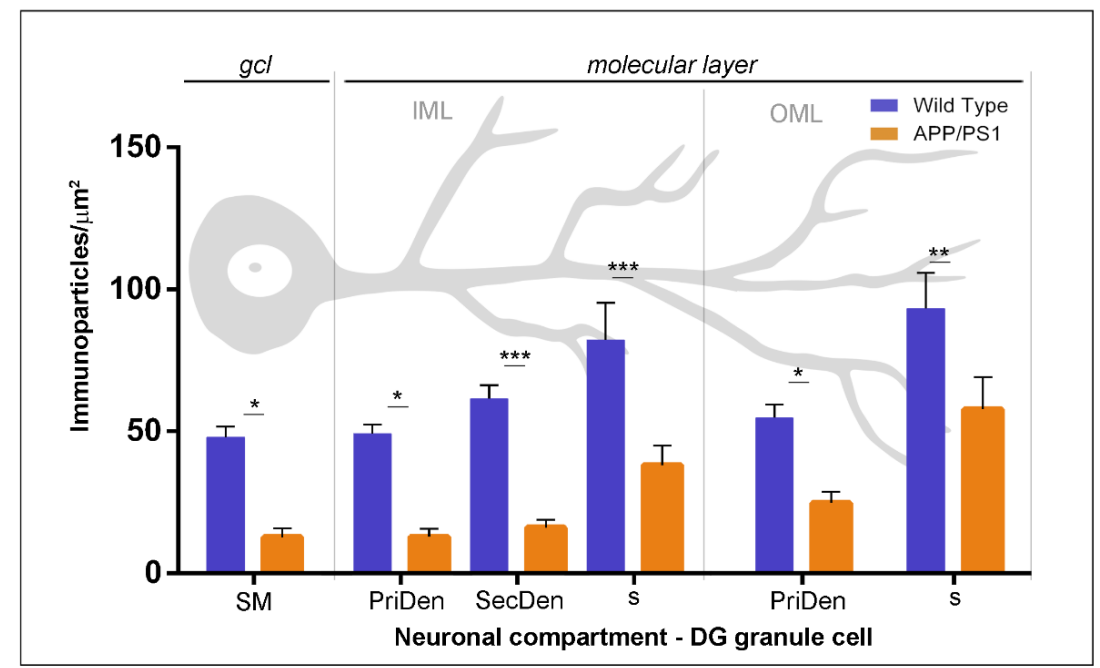

Figure 4. Density gradient of $\mathrm{GABA}_{\mathrm{B} 1}$ immunoparticles along the surface of granule cells in wild type and APP/PS1 mice at 12 months. Quantitative analysis of $\mathrm{GABA}_{\mathrm{B} 1}$ immunogold labelling in six neuronal compartments of DG granule cells. The density gradient of immunoparticles for $\mathrm{GABA}_{\mathrm{B} 1}$ along the neuronal surface was significantly reduced in all subfields and compartments of granule cells analysed in the APP/PS1 mice compared to age-matched wild type (Two-way ANOVA test $F_{(1,192)}=$ $70.78, p<0.0001$ (genotype) and Bonferroni post-hoc test, ${ }^{*} p<0.05$; ${ }^{* *} p<0.01$; ${ }^{* *} p<0.001$ ). Error bars indicate SEM. Abbreviations: PriDen, primary dendrite; SecDen, secondary dendrite; s, spine; $\mathrm{SM}$, soma.

Next, we performed a quantitative comparison of the $\mathrm{GABA}_{\mathrm{B} 1}$ densities in the six different somato-dendritic compartments of granule cells (Figure 4). In wild type, this analysis showed that $\mathrm{GABA}_{\mathrm{B} 1}$ was not evenly distributed along the neuronal surface in granule cells, but, instead, there was a graded increase in the density of $\mathrm{GABA}_{\mathrm{B} 1}$ immunoparticles from the soma to the dendritic spines (Figure 4). This distribution gradient was also detected in granule cells from APP/PS1 mice (Figure 4). 
However, our analysis demonstrated that $\mathrm{GABA}_{\mathrm{B} 1}$ density along the neuronal surface was significantly reduced in all compartments analysed in granule cells of the APP/PS1 mice compared to age-matched control mice at 12 months of age (two-way ANOVA test $F_{(1,192)}=70.78, p<0.0001$ (genotype) and Bonferroni post-hoc test, ${ }^{*} p<0.05 ;{ }^{* *} p<0.01$; ${ }^{* * *} p<0.001$ ) (Figure 4).

\subsection{Reduction in Presynaptic $G A B A_{B 1}$ in the Dentate Gyrus of APP/PS1 Mice}

In addition to somato-dendritic domains of DG granule cells, immunoparticles for $\mathrm{GABA}_{\mathrm{B} 1}$ were also detected presynaptically in axon terminals, consistent with previous reports [28-31]. Therefore, we next investigated whether the subcellular distribution of $\mathrm{GABA}_{\mathrm{B} 1}$ at presynaptic sites is altered in the inner one third and outer two thirds of the DG molecular layer of APP/PS1 at 12 months of age using the SDS-FRL technique (Figure 5). In wild type mice, immunoparticles for $\mathrm{GABA}_{\mathrm{B} 1}$ were found forming clusters and scattered outside the clusters in active zones of axon terminals, as well as along the extrasynaptic site of axon terminals, both in the outer two thirds (Figure 5A) and inner one third (Figure 5D) of the DG molecular layer. The density of immunoparticles for $\mathrm{GABA}_{\mathrm{B} 1}$ was higher at the active zones (AZ; inner one third $=288.12 \pm 50.29$ immunoparticles $/ \mu \mathrm{m}^{2}, n=269$ particles; outer two thirds $=379.49 \pm 36.27$ immunoparticles $/ \mu \mathrm{m}^{2}, n=667$ particles) than at extrasynaptic sites (Extra; inner one third $=41.28 \pm 11.14$ immunoparticles $/ \mu^{2}{ }^{2}, n=144$ particles; outer two thirds $=28.77 \pm 6.44$ immunoparticles $/ \mu^{2}{ }^{2}, n=200$ particles) (Figure 5C,F). In APP/PS1 mice, immunoparticles for GABA $\mathrm{B}_{1}$ showed the same presynaptic distribution in the outer two thirds (Figure 5B) and inner one third (Figure 5E) of the DG molecular layer than that described in wild type mice. However, quantitative comparisons with age-matched wild type mice showed significant differences in the density of $G_{A B A}$ immunoparticles in the active zone and extrasynaptic sites in the outer two thirds ( $\mathrm{AZ}=121.30 \pm 18.01$ immunoparticles $/ \mu^{2}{ }^{2}, n=76$ particles; Extra $=7.86 \pm 2.16$ immunoparticles $/ \mu \mathrm{m}^{2}, n=33$ particles) (Figure $5 \mathrm{C}$ ), and in the inner one third ( $\mathrm{AZ}=179.54 \pm 37.06 \mathrm{immunoparticles} / \mu \mathrm{m}^{2}, n=116$ particles; Extra $=7.67 \pm 1.95$ immunoparticles $/ \mu \mathrm{m}^{2}, n=33$ particles) (Figure $5 \mathrm{~F}$ ) (for AZ, Two-way ANOVA test $F_{(1,69)}=26.48, p<0.0001$ (genotype) and Bonferroni post-hoc test, ${ }^{*} p<0.05$; ${ }^{* * * *} p<0.0001$; and for extrasynaptic Two-way ANOVA test $F_{(1,69)}=17.09, p<0.0001$ (genotype) and Bonferroni post-hoc test, $\left.{ }^{* *} p<0.01\right)$.. In the two portions of the molecular layer, the reduction in the density of $\mathrm{GABA}_{\mathrm{B} 1}$ was higher in the outer two thirds than in the inner one third (Figure 5C,F), suggesting an input-dependent alteration of $\mathrm{GABA}_{\mathrm{B}}$ receptors.

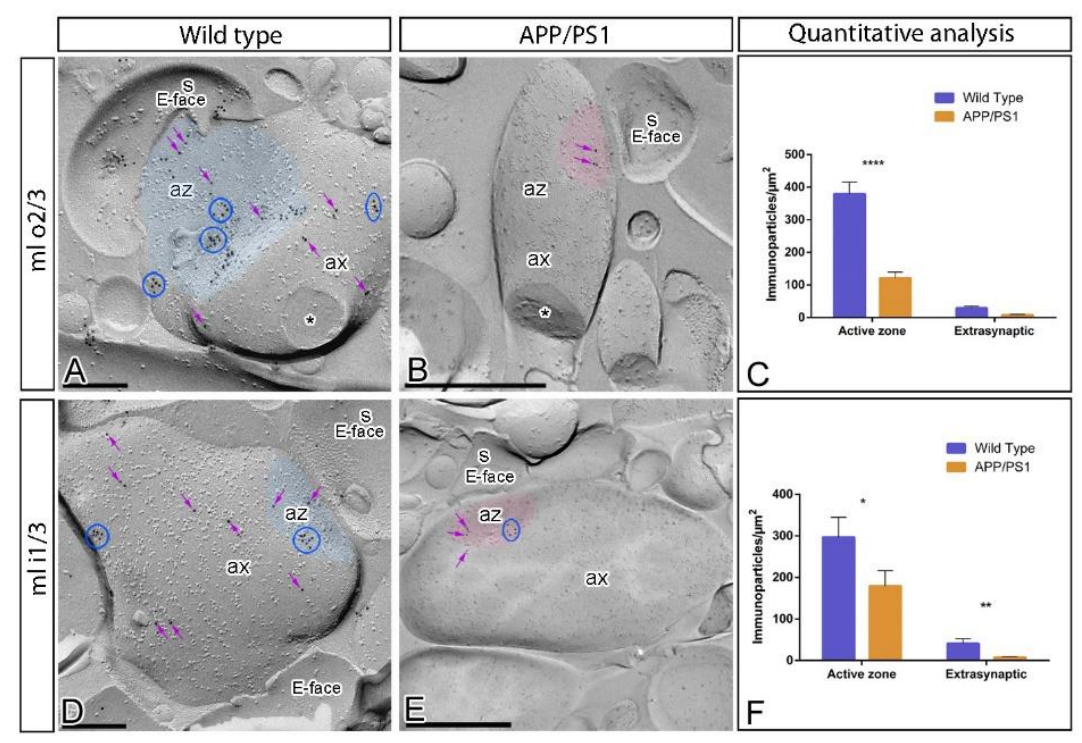

Figure 5. Presynaptic distribution of $\mathrm{GABA}_{\mathrm{B} 1}$ in the dentate gyrus in wild type and APP/PS1 mice. Electron micrographs showing immunoparticles for $\mathrm{GABA}_{\mathrm{B} 1}$ in presynaptic compartments in the outer two thirds ( $\mathrm{ml} \mathrm{o} 2 / 3)$ and inner one third ( $\mathrm{ml} \mathrm{i1} / 3)$ of the molecular layer of the DG at 12 months of age, 
as detected using the SDS-FRL technique. (A,D) In wild type, immunoparticles for GABA B1 $_{\text {were }}$ found forming clusters (blue ellipses/circles) and also detected scattered (purple arrows) outside the clusters within the active zone (az, blue transparent overlay) and along the extrasynaptic site of axon terminals (ax). (B,E) In APP/PS1, fewer immunoparticles for GABA $_{\mathrm{B} 1}$ forming clusters (blue ellipses/circles) or scattered (purple arrows), were detected within the active zone (az, red transparent overlay) and along the extrasynaptic plasma membrane of axon terminals (ax). Cross-fractures are indicated with asterisks $\left(^{*}\right)$. (C,F) Histograms illustrating densities of immunoparticles for GABA 1 in presynaptic compartments in the outer two thirds $(\mathrm{ml} \mathrm{o} 2 / 3)$ and inner one third $(\mathrm{ml} \mathrm{i} 1 / 3)$ of the molecular layer in wild type and APP/PS1 mice. Significant differences were detected in densities of $\mathrm{GABA}_{\mathrm{B} 1}$ immunoparticles in the outer two thirds of the molecular layer (Wild type: Active zone $(\mathrm{AZ})=379.49 \pm 36.27 \mathrm{immunoparticles} / \mu \mathrm{m}^{2}$ and Extra $=28.77 \pm 6.44 \mathrm{immunoparticles} / \mu \mathrm{m}^{2} ; \mathrm{APP} / \mathrm{PS} 1$ : $\left.\mathrm{AZ}=121.31 \pm 18.01 \mathrm{immunoparticles} / \mu \mathrm{m}^{2} ; \mathrm{Extra}=7.87 \pm 2.16 \mathrm{immunoparticles} / \mu \mathrm{m}^{2}\right)$, as well as in the inner one third of the molecular layer (Wild type: $A Z=288.12 \pm 50.29$ immunoparticles $/ \mu \mathrm{m}^{2}$ and Extra $=41.28 \pm 11.14$ immunoparticles $/ \mu m^{2} ; \mathrm{APP} / \mathrm{PS} 1: \mathrm{AZ}=179.54 \pm 37.06 \mathrm{immunoparticles} / \mu \mathrm{m}^{2} ;$ Extra $=$ $7.67 \pm 1.94$ immunoparticles $/ \mu \mathrm{m}^{2}$ ) (for AZ, Two-way ANOVA test $F_{(1,69)}=26.48, p<0.0001$ (genotype) and Bonferroni post-hoc test, ${ }^{*} p<0.05$; ${ }^{* * * *} p<0.0001$; and for extrasynaptic Two-way ANOVA test $F_{(1,69)}=17.09, p<0.0001$ (genotype) and Bonferroni post-hoc test, ${ }^{* *} p<0.01$ ). Error bars indicate SEM. Scale bars: A,D, $0.2 \mu \mathrm{m}$; B,E, $0.5 \mu \mathrm{m}$.

\section{4. $G A B A_{B 1}$ Is Increased in the Cytoplasm of Granule Cells in APP/PS1 Mice}

Finally, to explore the possibility that the reduction in $\mathrm{GABA}_{\mathrm{B} 1}$ along the membrane surface is due to its internalisation and accumulation at intracellular sites of granule cells and axon terminals of APP/PS1 mice at 12 months of age, we used the pre-embedding immunogold technique and quantitative analysis on tissue blocks taken from the inner molecular layer of the DG, where larger differences were

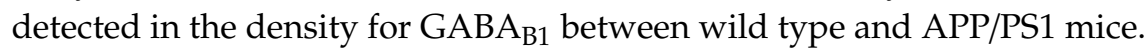

Postsynaptically, immunoparticles for $\mathrm{GABA}_{\mathrm{B} 1}$ were found along the extrasynaptic plasma membrane of dendritic spines and shafts of granule cells, as well as associated at intracellular sites in the same neuronal compartments, both in wild type and APP/PS1 mice (Figure 6). Quantitative analysis showed differences in the plasma membrane versus intracellular sites in the molecular layer (plasma membrane: $42.81 \%$ in wild type, $n=286$ particles, and $18.58 \%$ in APP/PS1, $n=943$ particles; intracellular: $57.19 \%$ in wild type, $n=382$ particles, and $81.42 \%$ in APP/PS1, $n=3224$ particles) of the DG (Figure 6E). This change in the plasma membrane versus the intracellular membrane labelling was detected both in dendritic spines (plasma membrane: $56 \%$ in wild type, $n=98$ particles, and $35.09 \%$ in APP/PS1, $n=189$ particles; intracellular: $44 \%$ in wild type, $n=77$ particles, and $64.90 \%$ in APP/PS1, $n=342$ particles) and dendritic shafts (plasma membrane: $39.77 \%$ in wild type, $n=171$ particles, and $16.17 \%$ in APP/PS1, $n=442$ particles; intracellular: $60.23 \%$ in wild type, $n=259$ particles, and $83.83 \%$ in APP/PS1, $n=2278$ particles) (Figure 6E). Presynaptically, immunoreactivity for GABA $\mathrm{B}_{1}$ was also detected in axon terminals establishing asymmetrical synapses with the dendritic spines of granule cells (Figure 6A-D). The quantitative analysis showed changes in the plasma membrane versus the intracellular membrane among wild type and APP/PS1 in the molecular layer (plasma membrane: $26.98 \%$ in wild type, $n=17$ particles, and 7.65\% in APP/PS1, $n=26$ particles; intracellular: $73.01 \%$ in wild type, $n=46$ particles, and $92.34 \%$ in APP/PS1, $n=222$ particles) (Figure 6E). 


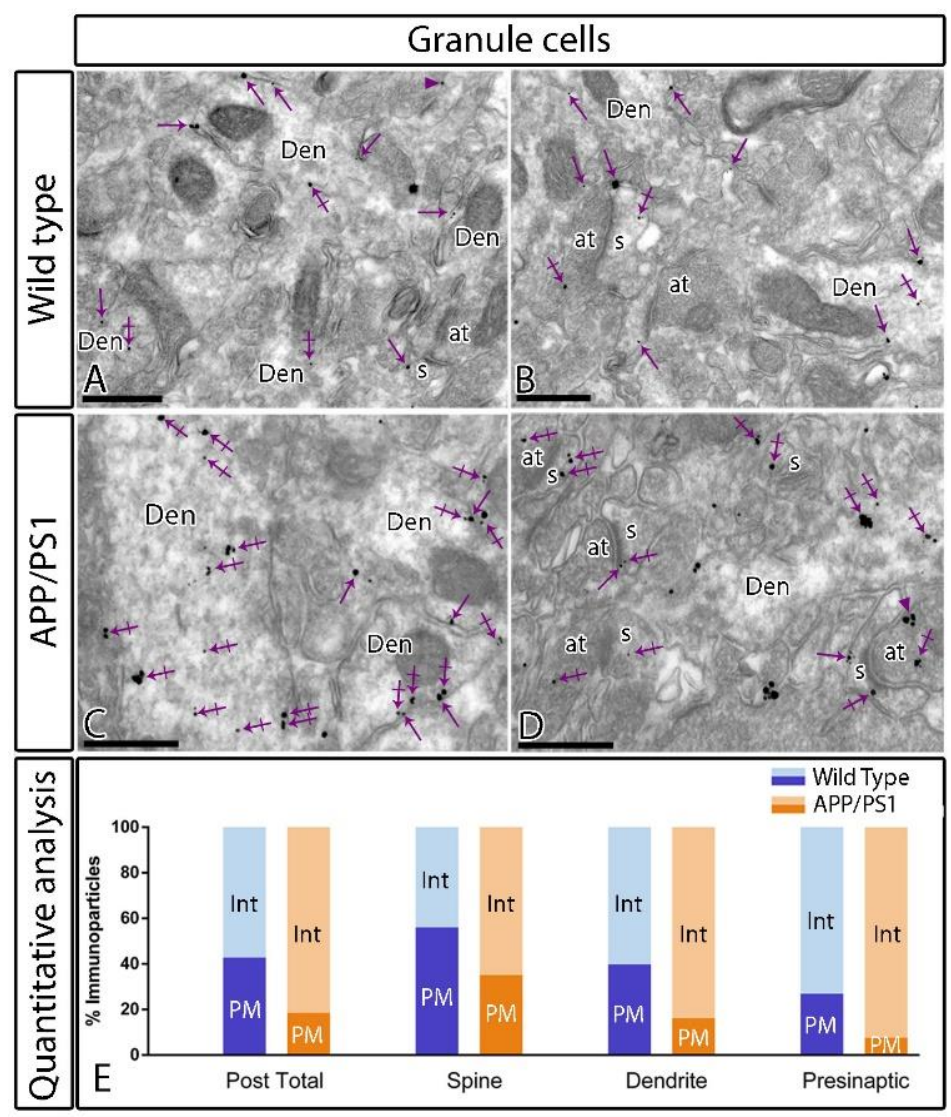

Figure 6. Intracellular distribution of $\mathrm{GABA}_{\mathrm{B} 1}$ is increased in the DG of APP/PS1 mice. Electron micrographs showing immunoparticles for $\mathrm{GABA}_{\mathrm{B} 1}$ in granule cells of the inner molecular layer of the DG at 12 months of age in wild type and APP/PS1 mice, as detected using a pre-embedding immunogold technique. (A-D) Both in wild type and APP/PS1 mice, GABA B1 $_{\text {immunoparticles were }}$ found along the extrasynaptic plasma membrane (arrows) and intracellular sites (crossed arrows) of dendritic shafts (Den) and spines (s) of granule cells contacted by axon terminals (at), and less frequently at presynaptic sites (arrowheads). (E) Quantitative analysis showed that immunoparticles for $\mathrm{GABA}_{\mathrm{B} 1}$ were less frequently observed along the extrasynaptic plasma membrane dendrites and spines of granule cells in APP/PS1 mice, as well at presynaptic sites, but, instead, they were more frequently detected at intracellular sites. Scale bars: A-D, $0.4 \mu \mathrm{m}$.

\section{Discussion}

The present study provides the first detailed description on the $2 \mathrm{D}$ mapping of $\mathrm{GABA}_{\mathrm{B}}$ receptors along the neuronal surface of DG granule cells, with particular emphasis on their possible alteration in a mouse model of Alzheimer's disease. Using light microscopy, we showed that GABA $\mathrm{B}_{1}$ receptors are widely distributed throughout the different areas of the DG with similar expression intensity and patterns in both wild type and APP/PS1 mice. However, using the SDS-FRL method, our data reveal a decrease in $\mathrm{GABA}_{\mathrm{B}}$ receptors along the plasma membrane of all subcellular postsynaptic compartments, and a parallel increase at intracellular sites, in DG granule cells at 12 months of age. We additionally reveal a decrease in presynaptic $\mathrm{GABA}_{B}$ receptors in axon terminals in the commissural/associational inputs and the entorhinal inputs, both contacting granule cells in a segregated manner. These reductions in postsynaptic and presynaptic $G_{A B A}$ receptors likely contribute to the pathology and memory impairment described in the APP/PS1 model of AD, providing new insights to understand the pathological events taking place in the disease. 


\subsection{Cellular Distribution of $G A B A_{B}$ Receptors in the Mouse Model of $A D$}

Dysfunction of the GABAergic system contributes to the modulation of learning and memory mechanism and function $[35,36]$. Accordingly, the inhibition of $G_{A B A}$ receptors improves learning and memory formation $[37,38]$ and altered $G_{A B A}$ receptor function has been involved in $A D$ pathogenesis [39]. Previous autoradiographic, in situ hybridisation and immunohistochemical reports showed that $D G$ contains high levels of $G A B A_{B}$ receptors [20,26,28,29]. At the cellular level, granule cells express transcripts for both $\mathrm{GABA}_{\mathrm{B} 1 \mathrm{a}}$ and $\mathrm{GABA}_{\mathrm{B} 1 \mathrm{~b}}$ subunits [27], although they are targeted to different synaptic sites to perform distinct functions [30]. Thus, mossy fibre terminals are immunopositive for the $\mathrm{GABA}_{\mathrm{B} 1 \mathrm{a}}$ subunit, whereas dendrites of granule cells are immunopositive for GABA $\mathrm{B}_{1 b}[30,40]$. In the present study, we used a pan-GABA ${ }_{B 1}$ antibody and, therefore, it was not possible to differentiate between the expression and distribution of both $\mathrm{GABA}_{\mathrm{B} 1 \mathrm{a}}$ and $\mathrm{GABA}_{\mathrm{B} 1 \mathrm{~b}}$ subunits in granule cells. However, immunoreactivity for the $\mathrm{GABA}_{\mathrm{B}}$ receptor subunit was predominantly enriched in the molecular layer of the DG, suggesting a mainly dendritic localisation.

Growing evidence shows that dysfunction of $\mathrm{GABA}_{B}$-mediated synaptic transmission underlies a number of disorders in the brain $[39,41-43]$. Given the role of $G_{A B A}$ receptors in learning and memory [37,42], their involvement in AD has also been suggested. Supporting this idea, recent studies reported not only that $\mathrm{GABA}_{\mathrm{B}}$ receptors selectively co-purify with APP [15], but also that $\mathrm{GABA}_{\mathrm{B}}$-APP macromolecular complexes link presynaptic $\mathrm{GABA}_{\mathrm{B}}$ receptor trafficking to $\mathrm{A} \beta$ formation [16]. In addition, autoradiography studies of $G A B A_{B}$ receptor expression in the human hippocampus of $A D$ patients demonstrated fewer $G_{A B A}$ receptors in the molecular layer of the dentate gyrus [44]. Here, we described that the regional and cellular distribution of $G_{A B A}$ receptors in the DG is virtually identical in APP/PS1 and control mice. Similarly, we have recently described that the expression of $\mathrm{GABA}_{\mathrm{B}}$ receptors does not change in the $\mathrm{CA} 1$ and $\mathrm{CA} 3$ regions of the hippocampus in the same mouse model of $\mathrm{AD}$, although expression is significantly reduced in the human hippocampus of AD patients [17].

These discrepancies could be likely due to differences in brain organisation between humans and mice [45], to the fact that the APP/PS1 model does not develop neurofibrillary tangles, a typical pathologic alteration observed in $\mathrm{AD}$ patients [46], or simply because the age of 12 months old used here, as well as by other laboratories, is still too short to detect gross changes. However, this mouse model shows reduced number of synapses per volume and the synaptic morphology in plaque-free regions of the DG outer molecular layer [10], and thus it is useful to detect possible alterations of synapse-associated receptors and/or ion channels [17].

\subsection{Altered Somato-Dendritic Localisation of GABA $A_{B}$ Receptors in APP/PS1 Granule Cells}

Using the SDS-FRL technique, we detected the majority of postsynaptic $G_{A B A} A_{B 1}$ immunoparticles along the extrasynaptic membrane of dendritic spines and shafts of granule cells, consistent with our immunoreactions at the light microscopic level. $G_{A B A}$ receptors localised to postsynaptic sites activate $G$ protein-gated inwardly rectifying $K+(G I R K)$ channels and are responsible for the slow inhibitory postsynaptic potentials IPSP $[47,48]$, and GABA $_{B}$ receptor-mediated slow inhibitory responses have been found in granule cells [31,49-52]. The prevalent localisation of $\mathrm{GABA}_{\mathrm{B} 1}$ in spines and dendrites we revealed here is in agreement with those electrophysiological observations showing the postsynaptic role of $\mathrm{GABA}_{B}$ receptors in granule cells. Interestingly, GIRK channels show a very similar somato-dendritic distribution than $\mathrm{GABA}_{B}$ receptors [31], suggesting that those $\mathrm{GABA}_{B}-\mathrm{GIRK}$ signalling cascade controls excitability in granule cell membranes.

The laminar arrangement of the cell bodies of granule cells in the DG allowed us to investigate changes in the density of $\mathrm{GABA}_{B}$ receptors in dendritic spines as a function of distance from the soma in wild type and APP/PS1 mice. The molecular layer is occupied mainly by the dendritic arbour of granule cells, as well as axons and terminal axonal arbours from the entorhinal cortex and other sources. Granule cells receive a major input from cells located in layer II of the entorhinal cortex, via the so-called perforant pathway. The entorhinal terminals are strictly confined to the outer two-thirds of 
the molecular layer where they form asymmetric synapses with spines of granule cells [53]. Inputs forming the commissural/associational pathway are limited to the inner one third of the molecular layer and largely contain axon terminals from the ipsilateral and contralateral hippocampus [53].

Given this anatomical organisation, quantitative comparison of immunogold densities revealed the distance- and subcellular compartment-specific distribution pattern of $G_{A B A}$ receptors on the surface of granule cells. Our high-resolution immunolocalisation experiments showed an increase in immunolabelling for $\mathrm{GABA}_{\mathrm{B} 1}$ from proximal to distal dendrites. Consistent with our morphological data, electrophysiological studies have shown that $\mathrm{GABA}_{\mathrm{B}}$ receptor-mediated currents are significantly larger in dendrites than in the somata of granule cells, and were markedly higher for the distal primary dendrites in the outer molecular layer [31]. Interestingly, GIRK channels show a very similar somato-dendritic distribution than $G_{A B A}$ receptors [31], suggesting that the $G_{A B} A_{B}-G I R K$ signalling cascade controls excitability in granule cell membranes.

In APP/PS1 mice, our analysis, performed at 12 months of age, also revealed distance-dependent and subcellular compartment-specific localisation of $\mathrm{GABA}_{\mathrm{B}}$ receptors in granule cells. However, the main finding of this study is the significant reduction in the membrane surface distribution of $\mathrm{GABA}_{\mathrm{B}}$ receptors in all subcellular compartments of granule cells. These findings are consistent with the evidence that the density of binding sites for $\mathrm{GABA}_{\mathrm{B}}$ receptors is decreased in molecular layer of the DG in human hippocampus with $\mathrm{AD}$ [44]. In addition, parallel to the decrease in the density of $\mathrm{GABA}_{\mathrm{B} 1}$ along the membrane surface, the application of different immunoelectron microscopy and quantitative analyses showed that there is an accumulation of immunoparticles at cytoplasmic sites in the dendrites and spines of granule cells. This pool of internalised $G_{A B A}$ receptors does not seem to be redirected to lysosomal degradation in $\mathrm{AD}$, not yet, at least, at 12 months of age. A similar internalisation has been recently described in CA1 pyramidal cells in the same mouse model [17], suggesting that different principal cells in the hippocampus use similar mechanisms to remove $G A B A_{B}$ receptors from the plasma membrane.

\subsection{Altered Presynaptic GABA $B$ Receptors in the Molecular Layer of APP/PS1 Mice}

In addition to the main presence of $\mathrm{GABA}_{\mathrm{B} 1}$ in somato-dendritic compartments of granule cells, we also found presynaptic labelling for this receptor subunit in the axon terminals establishing excitatory synapses in the molecular layer of the DG. Presynaptic labelling for $G_{A B A}$ receptors has been described in other regions of the hippocampus, including the CA1 and CA3 subfields $[17,28-30,54]$. Presynaptic activation of $\mathrm{GABA}_{B}$ receptors mediate slow and prolonged synaptic inhibition by inhibiting voltage-activated calcium (Cav) channels to result primarily in reduced vesicular release of neurotransmitter [13]. Using the SDS-FRL technique, we observed immunoparticles for GABA $\mathrm{B}_{\mathrm{B}}$ along the extrasynaptic membrane and the active zone of axon terminals located both in the outer two thirds and inner one third of the molecular layer, in agreement with previous studies using pre-embedding immunogold techniques [28,29]. However, in the mouse model of AD we not only found a reduction in the density of $\mathrm{GABA}_{\mathrm{B}}$ receptors in the inner and outer molecular layer, but also that the decrease was strongest in the termination area of the perforant pathway. Overall, these results are in good agreement with studies showing that the increase in $\mathrm{A} \beta$ production is linked to dysfunctional axonal trafficking and to the reduction in the expression of $\mathrm{GABA}_{\mathrm{B}}$ receptor in the APP knockout mice [16].

The functional consequences of this input-dependent reduction in $\mathrm{GABA}_{B}$ receptors is not yet known, but our data agrees with previous reports showing that AD pathology begins in the entorhinal cortex and spreads through the perforant pathway to the hippocampus [55]. Since the DG is a hippocampal region with a large accumulation of $\mathrm{A} \beta$ in $\mathrm{AD}$ [56], the larger decrease in the density of presynaptic $\mathrm{GABA}_{\mathrm{B}}$ receptors in the outer two thirds of the molecular layer may reflect changes due to entorhinal cortical pathology. However, since the perforant pathway lacks strong presynaptic $\mathrm{GABA}_{\mathrm{B}}$ receptor-mediated inhibition [57], the main effect produced by the reduction in $\mathrm{GABA}_{\mathrm{B}}$ receptor expression in the APP/PS1 mice mostly arises from postsynaptic receptors. Altogether, given the cognitive deficits observed in APP/PS1 mice [58], the pre- and post-synaptic reduction in 
$\mathrm{GABA}_{\mathrm{B}}$ receptors in granule cells, together with the alterations affecting other principal cells of the hippocampus [17], may represent the molecular and anatomical substrate of the altered cognitive function observed in this mouse model of AD. Supporting this idea, it has been shown that CGP55845, an antagonist of $\mathrm{GABA}_{\mathrm{B}}$ receptors, restored the memory of mice and augmented LTP [59]. More recently, the use of a different $\mathrm{GABA}_{\mathrm{B}}$ receptor antagonist, CGP35348, showed beneficial effects in improving cognition, learning, and memory in memory tests in acute $A \beta$ toxicity-induced rats [60]. These data indicate that potential therapeutics may target $\mathrm{GABA}_{\mathrm{B}}$ receptors in the hippocampus.

\section{Material and Methods}

\subsection{Animals}

The mouse line used for this study (APP/PS1; hemizygote animals) expressed the Mo/Hu APP695swe construct in conjunction with the exon-9-deleted variant of human presenilin 1 (PS1-dE9) [61]. Control mice were age-matched littermates without the transgene (wild type). Mice of all genotypes were aged to 12 months before use in a battery of morphological experiments. For each genotype, four mice were used for SDS-FRL techniques, three mice were used for immunohistochemistry at the light microscopic level and three mice were used for pre-embedding immunoelectron microscopic analyses. All mice were obtained from the Animal House Facility of the University of Castilla-La Mancha (Albacete, Spain). Animals were housed in cages of two or more mice, maintained on a $12 \mathrm{~h}$ light $/ 12 \mathrm{~h}$ dark cycle at $24^{\circ} \mathrm{C}$ and received food and water ad libitum. Both the care and handling of animals prior to and during experimental procedures were carried out in accordance with Spanish (RD 1201/2015) and European Union regulations (86/609/EC), and the protocols were approved (22 March 2019) by the local Animal Care and Use Committee.

For immunohistochemistry at the light and electron microscopic levels, animals were deeply anaesthetised by intraperitoneal injection of ketamine-xylazine $1: 1(0.1 \mathrm{~mL} / \mathrm{kg})$ or sodium pentobarbital (50 mg/kg, i.p.) and transcardially perfused with ice-cold fixative containing 1 ) $2 \%$ paraformaldehyde in $0.1 \mathrm{M}$ phosphate buffer (PB, pH 7.4) for $12 \mathrm{~min}$ (for SDS-FRL technique), or 2) $4 \%$ paraformaldehyde, $0.05 \%$ glutaraldehyde, and $15 \%(v / v)$ saturated picric acid made up in $0.1 \mathrm{M}$ phosphate buffer (PB), $\mathrm{pH} 7.4$ (for light microscopy and pre-embedding immunogold techniques). After perfusion, these brains were removed and coronal sections were cut on a Vibratome (Leica VT1000).

\subsection{Antibodies and Chemicals}

In the present study, we used the following primary antibodies: 1) An affinity-purified rabbit polyclonal antibody representing the amino acid sequence of $\mathrm{GABA}_{\mathrm{B} 1}$ (ref\#B17, residues 901-960 of rat $\left.\mathrm{GABA}_{\mathrm{B} 1}\right)$. This antibody has been characterised and the specificity proven elsewhere $[30,62,63]$; and 2 ) An affinity-purified rabbit polyclonal antibody anti- $\beta$ amyloid (ref \#2454, detecting both human A $\beta-40$ and A $\beta-42$ peptides; Cell Signalling Technology, Leiden, The Netherlands). In addition, we used the following secondary antibodies: alkaline phosphatase (AP)-goat anti-rabbit IgG (H+L) diluted 1:5000 (Invitrogen, Paisley, UK), goat anti-rabbit IgG coupled to $1.4 \mathrm{~nm}$ gold diluted 1:100 (Nanoprobes Inc., Stony Brook, NY, USA) and anti-rabbit IgG conjugated to $10 \mathrm{~nm}$ gold particles diluted 1: 100 (British Biocell International, Cardiff, UK).

\subsection{Immunohistochemistry for Light Microscopy}

The immunoperoxidase method was chosen to perform immunohistochemical reactions at the light microscopic level, as we described in detail previously [64]. Hippocampal sections were incubated for one hour in 10\% normal goat serum (NGS) diluted in $50 \mathrm{mM}$ Tris buffer (pH 7.4) containing $0.9 \%$ $\mathrm{NaCl}$ (TBS) and $0.2 \%$ Triton X-100. After several washes in TBS, hippocampal sections were incubated in the primary antibody (anti-GABA ${ }_{B 1}$ or anti- $\beta$ amyloid, both at a concentration of $1-2 \mu \mathrm{g} / \mathrm{mL}$ and diluted in TBS containing $1 \%$ NGS). Next, the sections were incubated in biotinylated goat anti-rabbit IgG (Vector Laboratories, Burlingame, CA, USA) diluted 1:200 in TBS containing 1\% NGS, and then 
transferred into avidin-biotin-peroxidase complex (ABC kit, Vector Laboratories). Next, we revealed peroxidase enzyme activity using the chromogen 3,3'-diaminobenzidine tetrahydrochloride (DAB; $0.05 \%$ in $\mathrm{TB}, \mathrm{pH} 7.4)$ and the substrate $\mathrm{H}_{2} \mathrm{O}_{2}(0.01 \%$ in distilled water). Hippocampal sections were then air-dried for few hours, mounted in DPX (Merk, Darmstadt, Germany), coverslipped and observed in a Leica photomicroscope (DM2000) equipped with differential interference contrast optics and a digital camera (DFC500).

\subsection{Immunohistochemistry for Electron Microscopy}

The pre-embedding immunogold and the SDS-digested freeze-fracture replica labelling (SDS-FRL) techniques were chosen to perform immunohistochemical reactions at the electron microscopic level, as we described in detail previously $[34,64,65]$.

\subsubsection{Pre-Embedding Immunogold Method}

Hippocampal sections obtained from both WT and APP/PS1 mice at 12 months of age were incubated in $10 \%$ NGS diluted in TBS.

After several washes in TBS, hippocampal sections were incubated in the primary antibody (anti-GABA $\mathrm{B}_{1}$ at a concentration of $3-5 \mu \mathrm{g} / \mathrm{mL}$ and diluted in TBS containing $1 \%$ NGS). After several washes in TBS, the sections were incubated in goat anti-rabbit IgG coupled to $1.4 \mathrm{~nm}$ gold (Nanoprobes Inc., Stony Brook, NY, USA). Next, hippocampal sections were postfixed in 1\% glutaraldehyde, washed in double-distilled water and silver enhancement of the gold particles (HQ Silver kit, Nanoprobes Inc.). Following treatment with osmium tetraoxide ( $1 \%$ in $0.1 \mathrm{M}$ phosphate buffer), block-staining with uranyl acetate and dehydration in graded series of ethanol, the sections were then flat-embedded on glass slides in Durcupan (Fluka) resin. After polymerization of the resin, regions of interest were cut at 70-90 nm on an ultramicrotome (Leica EM UC7, Leica, Wetzlar, Germany) and collected on pioloform-coated copper grids. Finally, ultrathin sections were stained on drops of $1 \%$ aqueous uranyl acetate and Reynolds's lead citrate. For ultrastructural analyses we used a JEOL-1010 electron microscope.

\subsubsection{SDS-FRL Technique}

Mice brains were perfused using 2\% paraformaldehyde in $0.1 \mathrm{M}$ phosphate buffer (PB) for $12 \mathrm{~min}$. Following several washes in $0.1 \mathrm{M} \mathrm{PB}$, the hippocampus was dissected and cut sagittal $(130 \mu \mathrm{m}$-thick sections) using a Microslicer (Dosaka, Kyoto, Japan). Hippocampal sections containing the DG were further trimmed down, immersed in graded glycerol of $10 \%-30 \%$ in $0.1 \mathrm{M} \mathrm{PB}$ at $4{ }^{\circ} \mathrm{C}$ overnight, and frozen using a high-pressure freezing machine (HPM010, BAL-TEC, Balzers, Liechtenstein). Next, DG slices were fractured into two parts at $-120^{\circ} \mathrm{C}$ and then replicated by depositions of carbon ( $5 \mathrm{~nm}$-thick), platinum ( $60^{\circ}$ unidirectional from horizontal level, $2 \mathrm{~nm}$-thick), and carbon (15-20 nm-thick) using a freeze-fracture replica machine (BAF060, BAL-TEC, Balzers). The resulting replicas were then transferred to $2.5 \%$ SDS and $20 \%$ sucrose in $15 \mathrm{mM}$ Tris buffer $(\mathrm{pH} 8.3)$ for $18 \mathrm{~h}$ at $80^{\circ} \mathrm{C}$ with shaking, washed three times in $50 \mathrm{mM}$ TBS (pH 7.4) containing $0.05 \%$ bovine serum albumin (BSA), and blocked with $5 \%$ BSA for $1 \mathrm{~h}$ at room temperature. After several washes in TBS containing $0.05 \%$ BSA, replicas were incubated in a polyclonal rabbit antibody for $\mathrm{GABA}_{\mathrm{B} 1}(5 \mu \mathrm{g} / \mathrm{mL})$ at $15^{\circ} \mathrm{C}$ overnight. Next, replicas were blocked in 5\% BSA/TBS and incubated in secondary antibodies conjugated with $10 \mathrm{~nm}$ gold particles overnight at room temperature. Finally, the replicas were rinsed with $0.05 \%$ BSA in TBS, washed with distilled water, and picked up onto grids coated with pioloform (Agar Scientific, Stansted, Essex, UK). For ultrastructural analyses, we used a JEOL-1010 electron microscope.

\subsection{Quantification and Analysis of SDS-FRL Data}

The labelled replicas were examined using a transmission electron microscope (JEOL-1010) and photographed at magnifications of 60,000, 80,000, and 100,000x. All antibodies used in this study were visualised by immunoparticles on the protoplasmic face (P-face), consistent with the intracellular location of their epitopes. Non-specific background labelling was measured on E-face surfaces in wild 
type mice. Digitised images were then modified for brightness and contrast using Adobe PhotoShop CS5 (Mountain View, CA, USA) to optimise them for quantitative analysis of immunolabelling. The quantitative analyses were done using the software Gold Particle Detection and Quantification (GPDQ), developed recently to perform automated and semi-automated detection of gold particles present in a given compartment of neurons [34].

\section{Density Gradient of $\mathrm{GABA}_{\mathrm{B} 1}$ along the Neuronal Surface}

The procedure was similar to that used previously [34]. Briefly, immunogold labelling for GABA $\mathrm{B}_{1}$ was achieved from replicas containing all three layers of the DG, so that the laminar distribution could be compared under identical conditions for each animal and experimental group. Quantitative analysis of immunogold labelling for $\mathrm{GABA}_{\mathrm{B} 1}$ was performed on five different dendritic compartments of granule cells in the molecular layer of the DG and in the somata of granule cells in the granule cell layer. The dendritic compartments analysed were the main dendritic shaft (primary dendrites), spiny branchlets (secondary dendrites) and dendritic spines. Secondary dendrites were identified based on their small diameter and the presence of at least one emerging spine from the dendritic shaft. Dendritic spines were considered as such if: (i) they emerged from a dendritic shaft, or (ii) they opposed an axon terminal. Axon terminals were identified based on: (i) the presence of an active zone (AZ) facing a postsynaptic density (PSD), recognised by an accumulation of intramembrane particles (IMPs), on the opposing exoplasmic-face (E-face) of a spine or dendrite with spines; or (ii) the presence of synaptic vesicles on their cross-fractured portions. Non-specific background labelling was measured on E-face structures surrounding the measured P-faces. Images of the identified compartments were selected randomly over the entire dendritic tree of granule cells and then captured with an ORIUS SC1000 CCD camera (Gatan, Munich, Germany). The area of the selected profiles and the number of immunoparticles were measured using our GPDQ software [34]. Immunoparticle densities were presented as mean \pm SEM between animals. Statistical comparisons were performed with GraphPad software (San Diego, CA, USA).

\subsection{Quantification and Analysis of Pre-Embedding Immunogold Data}

To establish the relative abundance of GABA $_{B 1}$ immunoreactivity in different compartments of granule cells between the two genotypes, pre-embedding immunogold immunohistochemistry was carried out [64]. Briefly, for each of three adult animals, three samples of tissue were obtained for the preparation of embedding blocks, thus using in total nine blocks. To minimise false negatives, electron microscopic serial ultrathin sections were cut close to the surface of each block, as immunoreactivity decreased with depth. We estimated the quality of immunolabelling by always selecting areas with optimal gold labelling at approximately the same distance from the cutting surface. Randomly selected areas were then photographed from the selected ultrathin sections and used with final magnification between 30,000 and 50,000 $\times$. Quantification of immunogold labelling was carried out in reference areas of the DG totalling approximately $2500 \mu^{2}$. We counted immunoparticles identified in each reference area and present in different subcellular compartments: dendritic spines, dendritic shafts, and axon terminals. The data were expressed as a percentage of immunoparticles in each subcellular compartment, both in the plasma membrane and at intracellular sites.

Finally, it is worth mentioning that neuronal loss is only observed adjacent to plaques in the APP/PS1 mouse model [10]. It should be noted that both in mouse models of AD and in AD patients, neurons in contact with $A \beta$ plaques suffer alterations in the morphology and number of dendritic spine, with destroyed tissue in dystrophic neurites [66-69], as well as in synaptic transmission [55,67,68,70,71]. To avoid this situation, our quantitative analysis was performed in A $\beta$ plaque-free regions of the DG. Thus, the density values expressed as immunoparticles $/ \mu \mathrm{m}^{2}$ in the APP/PS1 mice represent a genuine reduction in $\mathrm{GABA}_{\mathrm{B}}$ receptors in different compartments of granule cells, regardless of any possible neuronal and/or synaptic loss. 


\subsection{Controls}

To test method specificity in the procedures for electron microscopy, the primary antibody was either omitted or replaced with $5 \%(v / v)$ normal serum of the species of the primary antibody, resulting in total loss of the signal. For the pre-embedding technique, labelling patterns were also compared with those obtained with Calbindin (polyclonal rabbit anti-Calbindin D-9k CB9; Swant, Marly, Switzerland); only the antibodies against $\mathrm{GABA}_{\mathrm{B} 1}$ consistently labelled the plasma membrane.

\subsection{Data analysis}

Statistical analyses for morphological data were performed using SigmaStat Pro (Jandel Scientific) and data were presented as mean \pm SEM unless indicated otherwise. Statistical significance was defined as $p<0.05$. The statistical evaluation of the immunogold densities was performed using the two-way ANOVA test, and further compared with the Bonferroni post-hoc test.

Author Contributions: All authors had full access to all data in the study and take responsibility for the integrity of the data and the accuracy of the data analysis. R.L. and Y.F. designed the project; A.M.-B., R.L. and Y.F. performed SDS-FRL immunoelectron microscopy; A.M.-B., R.A.-R. and A.E.M.-M. performed light microscopy immunohistochemistry; L.d.l.O. developed in-house software and performed computational analysis; R.S. provided reagents and feedback on the quantitative analysis; J.M.-H. and A.B. provided APP/PS1 and WT tissues and feedback on the manuscript; A.M.-B., R.A.-R., C.A. and R.L. analysed data; R.L. wrote the paper. All authors have read and agreed to the published version of the manuscript.

Funding: This work was supported by grants from the Spanish Ministerio de Economía y Competitividad (BFU2015-63769-R and RTI2018-095812-B-I00) and Junta de Comunidades de Castilla-La Mancha (SBPLY/17/180501/000229) to R.L., and (SBPLY/17/180501/000493) to L.d.1.O, and Life Science Innovation Center (Research and Education Program for Life Science) at University of Fukui and JSPS KAKENHI Grant Numbers 16H04662, 17K19446, and 18H05120 to Y.F.

Acknowledgments: Funding sources were Spanish Ministerio de Economía y Competitividad, Junta de Comunidades de Castilla-La Mancha (Spain), and Life Science Innovation Center at University of Fukui.

Conflicts of Interest: The authors of this manuscript declare that they have no competing interests.

\section{References}

1. Amaral, D.G.; Scharfman, H.E.; Lavenex, P. The dentate gyrus: Fundamental neuroanatomical organization (dentate gyrus for dummies). Prog. Brain Res. 2007, 163, 3-22. [CrossRef]

2. Freund, T.F.; Buzsáki, G. Interneurons of the hippocampus. Hippocampus 1996, 6, 347-470. [CrossRef]

3. Kampa, B.M.; Gundlfinger, A.; Letzkus, J.J.; Leibold, C. Circuit mechanisms of memory formation. Neural Plast. 2011, 2011. [CrossRef]

4. Morrison, J.H.; Patrick, H.R. Life and Death of Neurons in the Aging Brain. Science (80-) 1997, 278, 412-419. [CrossRef]

5. Bloom, G.S. Amyloid- $\beta$ and tau: The trigger and bullet in Alzheimer disease pathogenesis. JAMA Neurol. 2014, 71, 505-508. [CrossRef]

6. Huang, Y.; Mucke, L. Alzheimer mechanisms and therapeutic strategies. Cell 2012, 148, 1204-1222. [CrossRef]

7. Scheff, S.; Sparks, D.L.; Price, D. Quantitative Assessment of Synaptic Density in the Outer Molecular Layer of the Hippocampal Dentate Gyrus in Alzheimer's Disease. Dement. Geriatr. Cogn. Disord. 1996, 7, $226-232$. [CrossRef]

8. Scheff, S.W.; Price, D.A. Synaptic Density in the Inner Molecular Layer of the Hippocampal Dentate Gyrus in Alzheimer Disease. J. Neuropathol. Exp. Neurol. 1998, 57, 1146-1153. [CrossRef]

9. Scheff, S.W.; Price, D.A. Synaptic pathology in Alzheimer's disease: A review of ultrastructural studies. Neurobiol. Aging 2003, 24, 1029-1046. [CrossRef]

10. Alonso-Nanclares, L.; Merino-Serrais, P.; Gonzalez, S.; Defelipe, J. Synaptic changes in the dentate gyrus of APP/PS1 transgenic mice revealed by electron microscopy. J. Neuropathol. Exp. Neurol. 2013, 72, $386-395$. [CrossRef]

11. Li, B.; Yamamori, H.; Tatebayashi, Y.; Shafit-Zagardo, B.; Tanimukai, H.; Chen, S.; Iqbal, K.; Grundke-Iqbal, I. Failure of Neuronal Maturation in Alzheimer Disease Dentate Gyrus. J. Neuropathol. Exp. Neurol. 2008, 67, 78-84. [CrossRef] [PubMed] 
12. Macdonald, R.L.; Olsen, R.W. GABA A Receptor Channels. Annu. Rev. Neurosci. 1994, 17, 569-602. [CrossRef] [PubMed]

13. Bettler, B.; Kaupmann, K.; Mosbacher, J.; Gassmann, M. Molecular Structure and Physiological Functions of GABA B Receptors. Physiol. Rev. 2004, 84, 835-867. [CrossRef] [PubMed]

14. Kaupmann, K.; Schuler, V.; Mosbacher, J.; Bischoff, S.; Bittiger, H.; Heid, J.; Froestl, W.; Leonhard, S.; Pfaff, T.; Karschin, A.; et al. Human $\gamma$-aminobutyric acid type B receptors are differentially expressed and regulate inwardly rectifying K+ channels. Proc. Natl. Acad. Sci. USA 1998, 95, 14991-14996. [CrossRef]

15. Schwenk, J.; Pérez-Garci, E.; Schneider, A.; Kollewe, A.; Gauthier-Kemper, A.; Fritzius, T.; Raveh, A.; Dinamarca, M.C.; Hanuschkin, A.; Bildl, W.; et al. Modular composition and dynamics of native GABA B receptors identified by high-resolution proteomics. Nat. Neurosci. 2016, 19, 233-242. [CrossRef]

16. Dinamarca, M.C.; Raveh, A.; Schneider, A.; Fritzius, T.; Früh, S.; Rem, P.D.; Stawarski, M.; Lalanne, T.; Turecek, R.; Choo, M.; et al. Complex formation of APP with GABA B receptors links axonal trafficking to amyloidogenic processing. Nat. Commun. 2019, 10,1-17. [CrossRef]

17. Martín-Belmonte, A.; Aguado, C.; Alfaro-Ruíz, R.; Moreno-Martínez, A.E.; de la Ossa, L.; Martínez-Hernández, J.; Buisson, A.; Früh, S.; Bettler, B.; Shigemoto, R.; et al. Reduction in the neuronal surface of post- and pre-synaptic GABA B receptors in the hippocampus in a mouse model of Alzheimer's disease. Brain Pathol. 2019, 12802. [CrossRef]

18. Rice, H.C.; De Malmazet, D.; Schreurs, A.; Frere, S.; Van Molle, I.; Volkov, A.N.; Creemers, E.; Vertkin, I.; Nys, J.; Ranaivoson, F.M.; et al. Secreted amyloid-B precursor protein functions as a GABABR1a ligand to modulate synaptic transmission. Science (80-) 2019, 363, 1-19. [CrossRef]

19. Tang, B.L. Amyloid Precursor Protein (APP) and GABAergic Neurotransmission. Cells 2019, 8, 550. [CrossRef]

20. Kaupmann, K.; Huggel, K.; Heid, J.; Flor, P.J.; Bischoff, S.; Mickel, S.J.; McMaster, G.; Angst, C.; Bittiger, H.; Froestl, W.; et al. Expression cloning of GABA(B) receptors uncovers similarity to metabotropic glutamate receptors. Nature 1997, 386, 239-246. [CrossRef]

21. Bowery, N.G.; Brown, D.A. The cloning of GABAB receptors. Nature 1997, 386, 223-224. [CrossRef]

22. Jones, K.A.; Borowsky, B.; Tamm, J.A.; Craig, D.A.; Durkin, M.M.; Dai, M.; Yao, W.; Johnson, M.; Gunwaldsen, C.; Huang, L.; et al. GABAB receptors function as a heteromeric assembly of the subunits GABABR1 and GABABR2. Nature 1998, 396, 674-679. [CrossRef]

23. Kaupmann, K.; Malitschek, B.; Schuler, V.; Heid, J.; Froestl, W.; Beck, P.; Mosbacher, J.; Bischoff, S.; Kulik, A.; Shigemoto, R.; et al. GABA(B)-receptor subtypes assemble into functional heteromeric complexes. Nature 1998, 396, 683-687. [CrossRef]

24. White, J.H.; Wise, A.; Main, M.J.; Green, A.; Fraser, N.J.; Disney, G.H.; Barnes, A.A.; Emson, P.; Foord, S.M.; Marshall, F.H. Heterodimerization is required for the formation of a functional GABAB receptor. Nature 1998, 396, 679-682. [CrossRef]

25. Kuner, R.; Körh, G.; Grünewald, S.; Eisenhardt, G.; Bach, A.; Kornau, H. Role of Heteromer Formation in GABAB Receptor Function. Science (80-) 1999, 283, 74-77. [CrossRef]

26. Chu, D.C.M.; Albin, R.L.; Young, A.B.; Penney, J.B. Distribution and kinetics of GABAB binding sites in rat central nervous system: A quantitative autoradiographic study. Neuroscience 1990, 34, 341-357. [CrossRef]

27. Bischoff, S.; Leonhard, S.; Reymann, N.; Schuler, V.; Shigemoto, R.; Kaupmann, K.; Bettler, B. Spatial distribution of GABA(B)R1 receptor mRNA and binding sites in the rat brain. J. Comp. Neurol. 1999, 412, 1-16. [CrossRef]

28. López-Bendito, G.; Shigemoto, R.; Kulik, A.; Vida, I.; Fairén, A.; Luján, R. Distribution of metabotropic GABA receptor subunits GABAB1a/b and GABAB2 in the rat hippocampus during prenatal and postnatal development. Hippocampus 2004, 14, 836-848. [CrossRef]

29. Kulik, Á.; Vida, I.; Luján, R.; Haas, C.A.; López-Bendito, G.; Shigemoto, R.; Frotscher, M. Subcellular Localization of Metabotropic GABA B Receptor Subunits GABA B1a/b and GABA B2 in the Rat Hippocampus. J. Neurosci. 2003, 23, 11026-11035. [CrossRef]

30. Vigot, R.; Barbieri, S.; Bräuner-Osborne, H.; Turecek, R.; Shigemoto, R.; Zhang, Y.P.; Luján, R.; Jacobson, L.H.; Biermann, B.; Fritschy, J.M.; et al. Differential Compartmentalization and Distinct Functions of GABA B Receptor Variants. Neuron 2006, 50, 589-601. [CrossRef]

31. Degro, C.E.; Kulik, A.; Booker, S.A.; Vida, I. Compartmental distribution of gabab receptor-mediated currents along the somatodendritic axis of hippocampal principal cells. Front. Synaptic Neurosci. 2015, 7, 1-15. [CrossRef] 
32. Garcia-Alloza, M.; Robbins, E.M.; Zhang-Nunes, S.X.; Purcell, S.M.; Betensky, R.A.; Raju, S.; Prada, C.; Greenberg, S.M.; Bacskai, B.J.; Frosch, M.P. Characterization of amyloid deposition in the APPswe/PS1dE9 mouse model of Alzheimer disease. Neurobiol. Dis. 2006, 24, 516-524. [CrossRef]

33. Gimbel, D.A.; Nygaard, H.B.; Coffey, E.E.; Gunther, E.C.; Laurén, J.; Gimbel, Z.A.; Strittmatter, S.M. Memory impairment in transgenic alzheimer mice requires cellular prion protein. J. Neurosci. 2010, 30, 6367-6374. [CrossRef]

34. Luján, R.; Aguado, C.; Ciruela, F.; Cózar, J.; Kleindienst, D.; de la Ossa, L.; Bettler, B.; Wickman, K.; Watanabe, M.; Shigemoto, R.; et al. Differential association of GABA B receptors with their effector ion channels in Purkinje cells. Brain Struct. Funct. 2018, 223, 1565-1587. [CrossRef]

35. Solas, M.; Puerta, E.; Ramirez, M. Treatment Options in Alzheimer's Disease: The GABA Story. Curr. Pharm. Des. 2015, 21, 4960-4971. [CrossRef]

36. Shahidi, S.; Komaki, A.; Mahmoodi, M.; Lashgari, R. The role of GABAergic transmission in the dentate gyrus on acquisition, consolidation and retrieval of an inhibitory avoidance learning and memory task in the rat. Brain Res. 2008, 1204, 87-93. [CrossRef]

37. Helm, K.A.; Haberman, R.P.; Dean, S.L.; Hoyt, E.C.; Melcher, T.; Lund, P.K.; Gallagher, M. GABA B receptor antagonist SGS742 improves spatial memory and reduces protein binding to the cAMP response element (CRE) in the hippocampus. Neuropharmacology 2005, 48, 956-964. [CrossRef]

38. Nazari, M.; Komaki, A.; Salehi, I.; Sarihi, A.; Shahidi, S.; Komaki, H.; Ganji, A. Interactive effects of AM251 and baclofen on synaptic plasticity in the rat dentate gyrus. Brain Res. 2016, 1651, 53-60. [CrossRef]

39. Dal Prà, I.; Armato, U.; Chiarini, A. Family C G-protein-coupled receptors in Alzheimer's disease and therapeutic implications. Front. Pharmacol. 2019, 10, 1-25. [CrossRef]

40. Guetg, N.; Seddik, R.; Vigot, R.; Turecek, R.; Gassmann, M.; Vogt, K.E.; Bräuner-Osborne, H.; Shigemoto, R.; Kretz, O.; Frotscher, M.; et al. The GABA B1a isoform mediates heterosynaptic depression at hippocampal mossy fiber synapses. J. Neurosci. 2009, 29, 1414-1423. [CrossRef]

41. Lujan, R.; Ciruela, F. GABAB Receptors-Associated Proteins: Potential Drug Targets in Neurological Disorders? Curr. Drug Targets 2012, 13, 129-144. [CrossRef]

42. Heaney, C.F.; Kinney, J.W. Role of GABAB receptors in learning and memory and neurological disorders. Neurosci. Biobehav. Rev. 2016, 63, 1-28. [CrossRef]

43. Fritzius, T.; Bettler, B. The organizing principle of GABA B receptor complexes: Physiological and pharmacological implications. Basic Clin. Pharmacol. Toxicol. 2019, 1-10. [CrossRef]

44. Chu, D.C.M.; Penney, J.B.; Young, A.B. Quantitative autoradiography of hippocampal GABAB and GABAA receptor changes in Alzheimer's disease. Neurosci. Lett. 1987, 82, 246-252. [CrossRef]

45. De Felipe, J. From the connectome to the synaptome: An epic love story. Science (80-) 2010, 330, $1198-1201$. [CrossRef]

46. Irizarry, M.C.; Mcnamara, M.; Fedorchak, K.; Hsiao, K.; Hyman, B.T. APPSW Transgenic Mice Develop Age-related A $\beta$ Deposits and Neuropil Abnormalities, but no Neuronal Loss in CA1. J. Neuropathol. Exp. Neurol. 1997, 56, 965-973. [CrossRef]

47. Lüscher, C.; Jan, L.Y.; Stoffel, M.; Malenka, R.C.; Nicoll, R.A. G Protein-Coupled Inwardly Rectifying K+ Channels (GIRKs) Mediate Postsynaptic but Not Presynaptic Transmitter Actions in Hippocampal Neurons. Neuron 1997, 19, 687-695. [CrossRef]

48. Koyrakh, L. Molecular and Cellular Diversity of Neuronal G-Protein-Gated Potassium Channels. J. Neurosci. 2005, 25, 11468-11478. [CrossRef]

49. Mott, D.D.; Xie, C.W.; Wilson, W.A.; Swartzwelder, H.S.; Lewis, D.V. GABA(B) autoreceptors mediate activity-dependent disinhibition and enhance signal transmission in the dentate gyrus. J. Neurophysiol. 1993, 69, 674-691. [CrossRef]

50. Brucato, F.H.; Mott, D.D.; Lewis, D.V.; Swartzwelder, H.S. GABAB receptors modulate synaptically-evoked responses in the rat dentate gyrus, in vivo. Brain Res. 1995, 677, 326-332. [CrossRef]

51. Foster, J.D.; Kitchen, I.; Bettler, B.; Chen, Y. GABAB receptor subtypes differentially modulate synaptic inhibition in the dentate gyrus to enhance granule cell output. Br. J. Pharmacol. 2013, 168, 1808-1819. [CrossRef] 
52. Mircheva, Y.; Peralta, M.R.; Tóth, K. Interplay of Entorhinal Input and Local Inhibitory Network in the Hippocampus at the Origin of Slow Inhibition in Granule Cells. J. Neurosci. 2019, 39, 6399-6413. [CrossRef]

53. Anderson, P.; Morris, R.; Amaral, D.; Bliss, T.; O'Kefefe, J. The Hippocampus Book; Anderson, P., Morris, R., Amaral, D., Bliss, T., O’Kefefe, J., Eds.; Oxford University Press: Oxford, UK, 2006. [CrossRef]

54. Fajardo-Serrano, A.; Wydeven, N.; Young, D.; Watanabe, M.; Shigemoto, R.; Martemyanov, K.A.; Wickman, K.; Luján, R. Association of Rgs7/Gß5 complexes with girk channels and GABAB receptors in hippocampal CA1 pyramidal neurons. Hippocampus 2013, 23, 1231-1245. [CrossRef]

55. Llorens-Martín, M.; Blazquez-Llorca, L.; Benavides-Piccione, R.; Rabano, A.; Hernandez, F.; Avila, J.; DeFelipe, J. Selective alterations of neurons and circuits related to early memory loss in Alzheimer's disease. Front. Neuroanat. 2014, 8, 1-12. [CrossRef]

56. Hyman, B.; Van Hoesen, G.; Damasio, A.; Barnes, C. Alzheimer's disease: Cell-specific pathology isolates the hippocampal formation. Science (80-) 1984, 225, 1168-1170. [CrossRef]

57. Lanthorn, T.H.; Cotman, C.W. Baclofen selectively inhibits excitatory synaptic transmission in the hippocampus. Brain Res. 1981, 225, 171-178. [CrossRef]

58. Malm, T.M.; Iivonen, H.; Goldsteins, G.; Keksa-Goldsteine, V.; Ahtoniemi, T.; Kanninen, K.; Salminen, A.; Auriola, S.; Van Groen, T.; Tanila, H.; et al. Pyrrolidine dithiocarbamate activates Akt and improves spatial learning in APP/PS1 mice without affecting $\beta$-amyloid burden. J. Neurosci. 2007, 27, 3712-3721. [CrossRef]

59. Kleschevnikov, A.M.; Belichenko, P.V.; Faizi, M.; Jacobs, L.F.; Htun, K.; Shamloo, M.; Mobley, W.C. Deficits in Cognition and Synaptic Plasticity in a Mouse Model of Down Syndrome Ameliorated by GABAB Receptor Antagonists. J. Neurosci. 2012, 32, 9217-9227. [CrossRef]

60. Almasi, A.; Zarei, M.; Raoufi, S.; Sarihi, A.; Salehi, I.; Komaki, A.; Hashemi-Firouzi, N.; Shahidi, S. Influence of hippocampal GABAB receptor inhibition on memory in rats with acute $\beta$-amyloid toxicity. Metab. Brain Dis. 2018, 33, 1859-1867. [CrossRef]

61. Scheuner, D.; Eckman, C.; Jensen, M.; Song, X.; Citron, M.; Suzuki, N.; Bird, T.D.; Hardy, J.; Hutton, M.; Kukull, W.; et al. Secreted amyloid $\beta$-protein similar to that in the senile plaques of Alzheimer's disease is increased in vivo by the presenilin 1 and 2 and APP mutations linked to familial Alzheimer's disease. Nat. Med. 1996, 2, 864-870. [CrossRef]

62. Kulik, Á.; Nakadate, K.; Nyíri, G.; Notomi, T.; Malitschek, B.; Bettler, B.; Shigemoto, R. Distinct localization of GABAB receptors relative to synaptic sites in the rat cerebellum and ventrobasal thalamus. Eur. J. Neurosci. 2002, 15, 291-307. [CrossRef]

63. Luján, R.; Shigemoto, R. Localization of metabotropic GABA receptor subunits GABAB1 and GABAB2 relative to synaptic sites in the rat developing cerebellum. Eur. J. Neurosci. 2006, 23, 1479-1490. [CrossRef]

64. Luján, R.; Nusser, Z.; Roberts, J.D.B.; Shigemoto, R.; Somogyi, P. Perisynaptic location of metabotropic glutamate receptors $m$ GluR1 and mGluR5 on dendrites and dendritic spines in the rat hippocampus. Eur. J. Neurosci. 1996, 8, 1488-1500. [CrossRef]

65. Tanaka, J.I.; Matsuzaki, M.; Tarusawa, E.; Momiyama, A.; Molnar, E.; Kasai, H.; Shigemoto, R. Number and density of AMPA receptors in single synapses in immature cerebellum. J. Neurosci. 2005, 25, 799-807. [CrossRef]

66. Merino-Serrais, P.; Knafo, S.; Alonso-Nanclares, L.; Fernaud-Espinosa, I.; Defelipe, J. Layer-specific alterations to CA1 dendritic spines in a mouse model of Alzheimer's disease. Hippocampus 2011, 21, 1037-1044. [CrossRef]

67. Spires, T.L.; Meyer-Luehmann, M.; Stern, E.A.; McLean, P.J.; Skoch, J.; Nguyen, P.T.; Bacskai, B.J.; Hyman, B.T. Dendritic spine abnormalities in amyloid precursor protein transgenic mice demonstrated by gene transfer and intravital multiphoton microscopy. J. Neurosci. 2005, 25, 7278-7287. [CrossRef]

68. Knafo, S.; Alonso-Nanclares, L.; Gonzalez-Soriano, J.; Merino-Serrais, P.; Fernaud-Espinosa, I.; Ferrer, I.; DeFelipe, J. Widespread changes in dendritic spines in a model of Alzheimer's Disease. Cereb. Cortex 2009, 19, 586-592. [CrossRef]

69. Merino-Serrais, P.; Benavides-Piccione, R.; Blazquez-Llorca, L.; Kastanauskaite, A.; Rábano, A.; Avila, J.; DeFelipe, J. The influence of phospho-tau on dendritic spines of cortical pyramidal neurons in patients with Alzheimer's disease. Brain 2013, 136, 1913-1928. [CrossRef] 
70. Terry, R.D.; Masliah, E.; Salmon, D.P.; Butters, N.; DeTeresa, R.; Hill, R.; Hansen, L.A.; Katzman, R. Physical basis of cognitive alterations in alzheimer's disease: Synapse loss is the major correlate of cognitive impairment. Ann. Neurol. 1991, 30, 572-580. [CrossRef]

71. Guo, J.L.; Lee, V.M.Y. Cell-to-cell transmission of pathogenic proteins in neurodegenerative diseases. Nat. Med. 2014, 20, 130-138. [CrossRef]

(C) 2020 by the authors. Licensee MDPI, Basel, Switzerland. This article is an open access article distributed under the terms and conditions of the Creative Commons Attribution (CC BY) license (http://creativecommons.org/licenses/by/4.0/). 